\title{
Production, Characterization and Application of Ferrate(VI) in Water and Wastewater Treatments
}

\author{
Alexis Munyengabe Caliphs Zvinowanda* $D$ \\ Department of Chemical Sciences, Faculty of Science, Doornfontein Campus, University of Johannesburg \\ Corner Nind and Beit Streets, P.O. Box 17011, Johannesburg, South Africa, 2028
}

Graphical Abstract

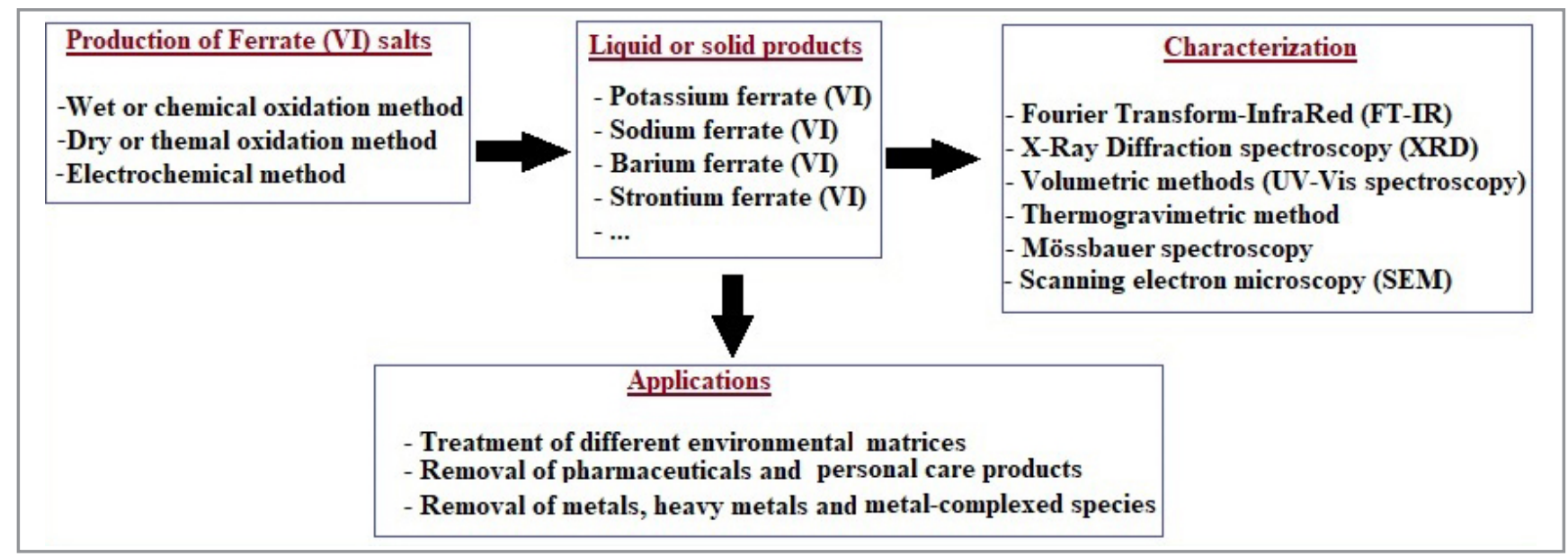

Investigation into the production, characterization and application of ferrate(VI) in water and wastewater treatment to enable metal removal through oxidation and coagulation processes and recommended in perspective for AMD treatment as a sustainable process.

This paper aimed at reviewing different research work done on the synthesis of ferrate(VI) salts of potassium and or sodium, their applications in industrial wastewater, municipal sewage and water treatment. In this review, it was found that ferrate $(\mathrm{VI})$ salt can exhibit more than one function in water and wastewater treatment as this chemical can take the roles of coagulants, flocculants, antioxidant, bactericide or disinfectant, and oxidant. Despite these properties, its availability on the market in a solid state is still a big problem due to its high cost and difficulties during its production as well as its chemical instability. Furthermore, suitable methods or procedures for manufacturing pure and stable ferrate( $\mathrm{VI})$ salts were established in the past decades but are too expensive to produce sufficient quantities required for a large-scale water and wastewater treatment. Current ferrate synthesis methods include wet chemical oxidation, dry and electrochemical techniques. Among them, the wet oxidation method is the most applicable and safe to generate ferrate $(\mathrm{VI})$ as dry and electrochemical methods can provoke detonation due to elevated temperatures and high concentration of electrolytes used, respectively. Some analytical techniques used to characterise and to quantify the ferrate(VI) products are scanning electron microscope, X-ray diffraction, infrared spectrometry, Mössbauer, ultraviolet-visible spectroscopy, thermogravimetric analysis, and volumetric methods. Several studies have been conducted to evaluate ferrate stability and its effective application in water and wastewater treatment. However, these studies showed that ferrate( $\mathrm{VI})$ can oxidise or degrade organic pollutants such as pharmaceuticals, illicit drugs, and can also destroy or eliminate suspended particulate organic matter in a single mixing and dosing unit procedure. The stability of ferrate $(\mathrm{VI})$ was found to depend on concentration, $\mathrm{pH}$, and temperature of the solution, and coexistence of ions in the solution. Lately, most researchers stated that ferrate(VI) can also be applied to treat different emerging micro-pollutants, viz., personal care products, industrial 
organic chemicals, endocrine disrupting chemicals, heavy metals, metal-complexed species, and others in water decontamination processes. Studies also showed that ferrate(VI) salt can be classified as a green chemical which can replace different disinfectants and oxidants producing toxic disinfectant by-products generated by the use of chemicals such as chlorine and chlorine dioxide. Mining industry is another sector, which still has a problem of high energy consumption during acid mine drainage (AMD) treatment. This is due to extensive stirring and aeration which required to facilitate the oxidation of $\mathrm{Fe}(\mathrm{II})$ ions. However, the authors recommend the use of ferrate $(\mathrm{VI})$ salt for $\mathrm{AMD}$ treatment as it can work as a powerful oxidant converting $\mathrm{Fe}(\mathrm{II})$ to $\mathrm{Fe}(\mathrm{III})$ and act as a coagulant in a single treating unit, hence, thus reducing energy consumption and environmental pollution problems.

Keywords: green chemical; coagulant; flocculant; oxidant; chemical stability; ferrate(VI) salts; water; wastewater

\section{INTRODUCTION}

Drinking water, domestic sewage and industrial effluent treatments are generally performed distinctively where different pollutants or contaminants are partially eliminated or completely degraded by the application of progressive modern technologies. There are various ways of water and wastewater treatments, which are based on different criteria. Conventional wastewater treatment consists of preliminary, primary, secondary and tertiary treatments that are based on biological, physical and chemical processes. For example, suspended solids, oil and small debris are removed during the primary treatment for municipal wastewater treatment while some physical parameters and phenols are reduced or removed in the secondary treatment. The most common biological process of wastewater treatment is a treatment with activated sludge. Bacteria, protozoa and microscopic metazoa use organic matter from wastewater as food and enhancement of biomass. Biological treatment offers high quality removal of suspended solids, 5-day biochemical oxygen demand (BOD5) and nutrients and waste sludge can be used in composting. Conventional biological treatment is highly efficient, uses less space compared to non-conventional treatments and their functioning is not dependent on outdoor conditions. Some of the disadvantages of these treatments are the constant high electrical energy requirements and the design, supervision, maintenance, and the general cost of construction that would require highly skilled workers [1]. The chemical pollution purification and subsequent reuse of treated water is performed in the tertiary treatment using electrodialysis, ion-exchange, oxidation, membrane ultrafiltration and reverse osmosis techniques [2]. These stages for conventional wastewater treatment to generate potable water consume a huge amount of energy through constant stirring, aeration and pumping at high pressure to generate treated water of either industrial or potable quality. Other wastewater treatment stages such as flocculation, coagulation and neutralisation are also characterised by limited effectiveness as they do not completely remove different pollutants usually found in environmental matrices. Although these techniques are commonly applied in water and wastewater treatment, some of them are known to produce toxic by-products, use too much and expensive neutralising agents (e.g. lime) especially in the case of acid mine drainage treatment. To solve this problem, however, advanced oxidation processes (AOPs) were being given serious consideration as an alternative to the existing water treatment procedures [3]. However, these AOPs normally use free radicals produced by various methods [4-6]. These free radicals contain unpaired valence electrons, which react to oxidize a wide range of microcontaminants, making them useful in water and wastewater treatment. One of the earliest methods of producing hydroxyl radicals in industrial waters was the use of Fenton's reagent, using ferrous iron $\left(\mathrm{Fe}^{2+}\right)$ to decompose hydrogen peroxide $\left(\mathrm{H}_{2} \mathrm{O}_{2}\right)$ to form $\mathrm{OH}$ before being reduced back to ferrous iron to produce another radical and water [7]. However, the use of AOPs involving the hydroxyl radical can increase oxidation of contaminants due to the radical's higher reactivity when compared to ozone or other conventional oxidants. Hydroxyl free radicals are strong oxidants with an oxidation potential of $2.80 \mathrm{~V}$ compared to ozone $(2.07 \mathrm{~V})$ and chlorine $(1.36 \mathrm{~V})$ and can oxidize organics including 
those resistant to ozone such as some pesticides and volatile organic compounds. Methods commonly used to generate hydroxyl radical now include combinations of ozone and ultraviolet radiation with hydrogen peroxide. Ozone can react with hydrogen peroxide or, through a series of reactions involving hydroxide ions, form the hydroxyl radical [7]. Nowadays, researchers are no longer using free radicals because of expensive reagents such as ozone and long process to produce them. Another promising AOP that has been currently investigated to treat water and industrial wastewater is ferrate(VI) in the form of either potassium ferrate( $\mathrm{VI})$ or sodium ferrate $(\mathrm{VI})$. This AOP can concurrently act either as a disinfectant, coagulant or oxidant in a single mixing and dosing unit procedure [8]. The ferrate( $\mathrm{VI})$ ion $\left(\mathrm{FeO}_{4}{ }^{2-}\right)$ is a typical oxyanion of iron with an oxidation state +6 , which has an orthorhombic structure and a tetrahedral form when different ferrate $(\mathrm{VI})$ salts are dissolved in water [9]. Its structure is very close to those of chromate and permanganate oxyanions, wherein four oxygen atoms are covalently attached to a central iron atom $[10,11]$. Even if chromate and permanganate can also be used as strong oxidants, researchers reported them to generate hazardous by-products (chromium and manganese) in water and wastewater treatment.

In general, iron usually exists as a metallic iron with zero valence, +2 and +3 in ferrous and ferric forms. The most known of these ferric or ferrous oxides include hematite, wuestite, magnetite, hypoferrite, ferrite, goethite, and akageneite [12]. Some of them such as magnetite and akageneite are currently utilised as powerful adsorbents in water, brine water and industrial wastewater treatment [13,14]. Iron can also appear in different forms with high oxidation states such as ferrate(IV) $\left[\mathrm{FeO}_{4}\right]^{4-}$, ferrate(IV) $\left[\mathrm{FeO}_{3}\right]^{2-}$, ferrate $(\mathrm{V})\left[\mathrm{FeO}_{4}\right]^{3-}$, ferrate $(\mathrm{VI})\left[\mathrm{FeO}_{4}\right]^{2-}$, ferrate $(\mathrm{VII})\left[\mathrm{FeO}_{4}\right]^{-}$, and ferrate $(\mathrm{VIII})\left[\mathrm{FeO}_{5}\right]^{2-}[15,16]$. However, the ferrate $(\mathrm{VI})$ ion has been studied progressively in the past years amongst other ferrate salts as a powerful flocculant, coagulant and disinfectant of emerging micropollutants [9,17-19] and also as a strong oxidant of inorganic and organic compounds in water and industrial wastewater treatment processes due to its high oxidation potential in wide range of $\mathrm{pH}$ values [20-27]. Over this entire $\mathrm{pH}$ range, ferrate $(\mathrm{VI})$ can oxidise different pollutants by substituting existing oxidants of environmental concern (chlorine, chromate, permanganate, chloramines and ozone), that can cause the production of many disinfectant by-products (DBPs) of concern $[9,19,28,29]$. Some occurrences of generated lethal DBPs that have been revealed to be cancer-causing in humans and animals include trihalomethanes [30]. These pollutants are normally generated when chlorinated disinfectants and chlorine are utilised to remove microbial pollutants from water by reacting with naturally-occurring inorganic and organic materials [21,31,32]. Epidemiological studies also recommended some relationship between the drinking water treated with the chlorine and the prevalence of colon, bladder and rectal cancer $[30,33]$. Comparing with chlorination treatment, the by-products being generated through the application sequestration of ferrate(VI) salts are environmentally-friendly ferric-based chemicals, that can also be served as an effective coagulant in water and wastewater treatment [22,24,34]. Ferrate(VI) has also been applied in different fields such as non-chlorine oxidation for pollutant remediation, catalyst in the green chemistry synthesis and in the fabrication of a super iron battery [34,35]. Moreover, the ferrate(VI) can also provide an environmentally-friendly high energy density cathode for battery and exhibits different properties such as high functional group selectivity as well as high oxidising power [21]. The redo potentials of ferrate $(\mathrm{VI})$ vary from $+2.20 \mathrm{~V}\left(\mathrm{E}^{\circ} \mathrm{FeO}_{4}{ }^{2-} / \mathrm{Fe}^{3+}\right)$ to $+0.72 \mathrm{~V}\left[\mathrm{E}^{\circ} \mathrm{FeO}_{4}{ }^{2-/} \mathrm{Fe}(\mathrm{OH})_{3}\right]$ in acidic $(\mathrm{pH}=1)$ and alkaline $(\mathrm{pH}=14)$ solutions, respectively $(30,36,37]$. Application of ferrate $(\mathrm{VI})$ as a powerful steriliser in water and industrial waste effluent treatments has been widely reviewed by Machala et al. [38]. The oxidization and disinfection capacities of commonly used compounds in water and wastewater treatment are presented in Figure 1, which is easily comparable to ferrate(VI). 


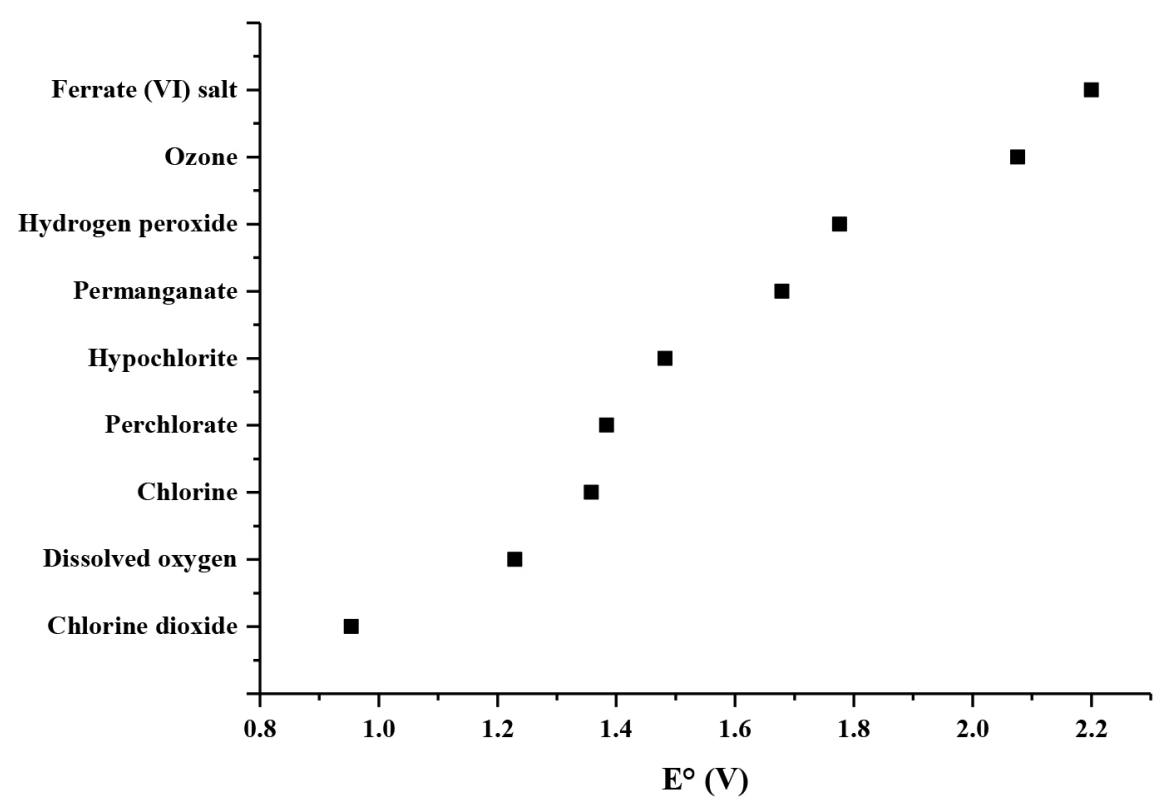

Figure 1. Comparison of current disinfectants and oxidant ability to use for treatment of water and wastewater.

In some studies, the results suggested a permanent inactivation of bacteria by ferrate(VI) with a kill rate of $99.9 \%$, while a significant resistance of bacteria to chlorination treatment was highlighted $[39,40]$. Ferrate $(\mathrm{VI})$ is also beneficial in the coagulation process where it can be used in a pre-oxidation stage of the water treatment [41]. Notably, all the above properties of ferrate(VI) can thus made it be utilised in a single dose for reuse and recycling of water and wastewater [38]. According to its exceptional properties, ferrate(VI) have encouraged several investigators to examine its effectiveness in water and wastewater treatment in comparison with other coagulants and oxidants such as ferric sulphate, chlorine, sodium hypochlorite, aluminum sulphate, ozone, ferric chloride, and chlorine dioxide [40]. However, the challenges have been raised for the application of ferrate $(\mathrm{VI})$ technology in practice due to the high production cost of solid ferrate $(\mathrm{VI})$ products or chemical instability of a ferrate(VI) solution [42]. To reach an effective treatment, research has been focused on the production and application of ferrate $(\mathrm{VI})$ salts in-situ to avoid its degradation through transportation $[17,43]$.

This paper reviewed the progress made in the production of ferrate(VI) salts based on electrochemical, wet oxidation and dry methods, stability and characterization methods of the product as well as its application in water and wastewater treatment. Analytical techniques currently used to characterise and to quantify the ferrate $(\mathrm{VI})$ ion have also been reviewed, namely: infrared spectrometry, X-ray diffraction, scanning electron microscopy, Mössbauer and ultraviolet-visible spectroscopy, thermogravimetric analysis and volumetric titration method [44,45]. Different studies carried out on the application of ferrate $(\mathrm{VI})$ in water, domestic sewage and wastewater treatment are also presented in this review. The authors concentrated on the current processes made in the potential use of ferrate $(\mathrm{VI})$ in water treatment, decomposition of organic and inorganic contaminants, emerging micropollutants and the analysis of the toxicity organic by-products generated from ferrate(VI) salts in treated water and wastewater. Lastly, the authors recommend continuing to implement this multifunction chemical (disinfectant, coagulant, oxidant, and flocculant) in practice for the future research, especially in water and wastewater as well as in acid mine drainage treatment.

\section{PRODUCTION OF FERRATE(VI) SALTS}

Different ferrate $(\mathrm{VI})$ salts are now being produced by mixing potassium nitrate and iron filings at high temperature [17]. After dissolving the molten residue in water, an unstable red-purple compound 
appears by revealing the existence of potassium ferrate $\left(\mathrm{K}_{2} \mathrm{Fe}^{\mathrm{V} I} \mathrm{O}_{4}\right)$ in the solution. Moreover, some methods have been successfully confirmed during the production of different ferrate(VI) salts, viz., wet oxidation, dry oxidation or thermal and electrochemical methods $[22,46]$. Among these methods, the electrochemical method was the one which attracted many researchers in the $20^{\text {th }}$ century. Normally, the ferrate $(\mathrm{VI})$ salts can be formed with the chemical formula $\mathrm{M}_{\mathrm{x}} \mathrm{FeO}_{4}$, where $\mathrm{M}$ stands for two atoms of $\mathrm{K}, \mathrm{Na}, \mathrm{Ag}, \mathrm{Cs}$ or one atom of $\mathrm{Ba}$ or $\mathrm{Ca}[47]$. Ferrate(VI) salts may be prepared using iron(III) salts either in solid state or liquid solutions such as ferric chloride, ferric nitrate, ferric sulphate or ferrous salts with an oxidant containing chloride ion (e.g. hypochlorite) in a strong base such as sodium carbonate and sodium hydroxide for wet oxidation method and the reaction of ferric oxides with sodium peroxide for dry method [48-50]. Other mixed cation ferrates such as potassium-sodium double ferrate and potassiumstrontium double ferrate(VI) salts can also be synthesised. For example, potassium-sodium double ferrate can be synthesised by adding potassium hydroxide to $40 \%$ sodium hydroxide containing $0.1 \mathrm{M}$ ferrate ions [51]. However, the crystals that precipitated out of the reaction are collected and washed and dried under a vacuum while potassium-strontium double ferrate $(\mathrm{VI})$ is produced by precipitating with an alkaline solution of nitrate from a slightly alkaline solution of potassium ferrate [51]. These promising methods for synthesising ferrate $(\mathrm{VI})$ are briefly described in the next paragraphs.

\section{Wet oxidation method for ferrate production}

The wet oxidation method for ferrate production has been extensively used by several researchers to produce solid or liquid ferrate, especially sodium and potassium ferrate(VI) [52-54]. Generally, this method uses cheap and less toxic chemicals such as sodium hypochlorite, any source of ferric ions, and alkalis such as sodium hydroxide, potassium hydroxide, calcium hydroxide, which are also familiarly used in the treatment of water and industrial wastewater. Researchers have preferred to utilise either ferrous or ferric salts as a main source of iron to be oxidised into ferrate(VI), calcium or sodium hypochlorite preferably with higher concentrations greater than $12 \%$ or sodium thiosulphate or chlorine as oxidisers, and sodium hydroxide or carbonate or potassium hydroxide to increase the $\mathrm{pH}$ of the medium [17]. For instance, Thompson et al. [52] reacted liquid $\mathrm{FeCl}_{3}$ with $\mathrm{NaOCl}$ in the presence of $\mathrm{NaOH}$ to yield a sodium ferrate $\left(\mathrm{Na}_{2} \mathrm{Fe}^{\mathrm{VI}} \mathrm{O}_{4}\right)$ as shown in Equation 1.

$$
2 \mathrm{FeCl}_{3(1)}+3 \mathrm{NaOCl}_{(1)}+10 \mathrm{NaOH}_{(l)} \rightarrow 2 \mathrm{Na}_{2} \mathrm{FeO}_{4(1)}+9 \mathrm{NaCl}_{(\mathrm{s})}+5 \mathrm{H}_{2} \mathrm{O}_{(1)}
$$

From equation 1 , ferric chloride is the iron source and can be replaced by other ferrous or ferric salts such as ferrous sulphate heptahydrate, ferric nitrate nonahydrate, ferric hydroxide or oxide, and ferric sulphate nonahydrate, etc. In some case, the mentioned oxidisers can also be replaced by a chlorine gas. Numerous measures have been set to synthesise solid $\mathrm{Na}_{2} \mathrm{FeO}_{4}$, though, there were many complications in separating any solid products from the resulting solutions, as this ferrate salt has a high solubility in a concentrated $\mathrm{NaOH}$ solution [28]. For the purpose of raising the ferrate( $\mathrm{VI})$ production efficiency, $\mathrm{KOH}$ replaced $\mathrm{NaOH}$ and thus the transitional formation of $\mathrm{Na}_{2} \mathrm{FeO}_{4}$ in the synthesis was stopped. Therefore, the yield of $\mathrm{K}_{2} \mathrm{Fe}(\mathrm{VI}) \mathrm{O}_{4}$ salt increased up to $75 \%$. The high purity of the solid product can be made up to $99 \%$, by a precipitation process where $\mathrm{K}_{2} \mathrm{FeO}_{4}$ can be isolated or precipitated out from the potassium hydroxide solution as shown in Equation 2 and by carrying out numerous dissolution and precipitation steps $[55,56]$. Though, the process consumes a lot of alkali solutions and thus, has made the high purity ferrate(VI) salts very expensive $[17,53,57]$.

$$
\mathrm{Na}_{2} \mathrm{FeO}_{4(\mathrm{l})}+2 \mathrm{KOH}_{(\mathrm{l})} \rightarrow \mathrm{K}_{2} \mathrm{FeO}_{4(\mathrm{~s})} \downarrow+2 \mathrm{NaOH}_{(\mathrm{l})}
$$

The preparation of other alkali metal ferrate(VI) salts such as rubidium or caesium ferrate(VI) can also follow the same procedure of sodium and potassium. In addition, through this wet method, alkaline earth metal ferrate $(\mathrm{VI})$ salts such as strontium or barium can also be prepared in a highly alkaline 
potassium ferrate(VI) as shown in Equation $3[48,49,57]$.

$$
\mathrm{K}_{2} \mathrm{FeO}_{4(\mathrm{~s})}+\mathrm{BaCl}_{2(\mathrm{~s})} \rightarrow \mathrm{BaFeO}_{4(\mathrm{~s})}+2 \mathrm{KCl}_{(\mathrm{s})}
$$

However, the application of barium ferrate in water and wastewater treatment is constrained by the toxicity of barium ion released. Hence, ideally ferrate salts should include counter ions such as sodium, potassium, magnesium and calcium with no toxicity in product water. The production of ferrate by wet methods is widely reported in literature, however, the solution of ferrate produced is highly unstable. Hence, more studies need to be done to produce either solid or liquid ferrate of high stability at high concentrations in order to use it in water and wastewater treatment conveniently.

\section{Thermal method for ferrate production}

The thermal method for ferrate production which is also known as the dry oxidation method has been intensively used in the beginning as a trial method by many researchers to synthesise solid ferrate salts [58]. These researchers produced ferrate salts by calcinating together iron filings with nitrates or by mixing iron oxides with alkali and nitrates at high temperature [58,59]. Ferrate salts can also be prepared using the thermal method by calcinating a mixture of $\mathrm{K}_{2} \mathrm{O}_{2}$ with $\mathrm{Fe}_{2} \mathrm{O}_{3}$ or by heating $\mathrm{Fe}_{2} \mathrm{O}_{3}$ with $\mathrm{Na}_{2} \mathrm{O}_{2}$ at elevated temperature and pressure with a continuous flow of dry oxygen $[17,58]$. However, the resulting products were considered to contain $\mathrm{Fe}_{4} \mathrm{O}_{5}{ }^{4-}$ anions, which can be further hydrolysed to form a tetrahedral $\mathrm{FeO}_{4}{ }^{2-}$ ion as shown in Equation 4, resulting in a red-violet solution [60].

$$
\mathrm{Fe} 4 \mathrm{O}_{5}^{4-}{ }_{(\mathrm{s})}+\mathrm{H}_{2} \mathrm{O}_{(\mathrm{l})} \rightarrow \mathrm{FeO}_{4}^{2-}{ }_{(\mathrm{aq})}+2 \mathrm{OH}^{-}{ }_{(\mathrm{aq})}
$$

To avoid detonation, this method has been tried at room temperature by several $[23,61,62]$. For example, Evrard et al. [61] combined ferrous sulphate heptahydrate with calcium hypochlorite to produce potassium sulphatoferrate as shown in Equation 5.

$$
2 \mathrm{FeSO}_{4} \cdot 7 \mathrm{H}_{2} \mathrm{O}_{(\mathrm{s})}+\mathrm{Ca}(\mathrm{ClO})_{2(\mathrm{aq})}+6 \mathrm{KOH}_{(\mathrm{s})} \rightarrow 2 \mathrm{~K}_{2}(\mathrm{Fe}, \mathrm{S})_{1 / 2} \mathrm{O}_{4(\mathrm{aq})}+2 \mathrm{KCl}_{(\mathrm{aq})}+\mathrm{Ca}(\mathrm{OH})_{2(\mathrm{aq})}+9 \mathrm{H}_{2} \mathrm{O}_{(1)}
$$

Even though this process has been comparatively recognised as high production efficiency of ferrate(VI), it has been considered as non-economic since calcium hypochlorite is still an expensive oxidant [23]. Therefore, Kanari et al. [62] substituted calcium hypochlorite by chlorine for the oxidation of ferrous sulphate. The dry synthesis at high temperature is an advantageous process compared to the wet method, which may cause the decomposition of the final product in an aqueous medium. At the same time, the thermal method has got its own limitation, showing a lower thermal stability. Even if this method can look to be a green technology because of recycling various iron waste materials, it is no longer being used to prepare ferrate $(\mathrm{VI})$ salts due to the fact that elevated temperatures can enhance detonation, which is considered dangerous and too difficult to control. There is no or little evidence in literature to support the use of thermal method for mass production of ferrate to meet the needs of water and wastewater treatment sectors. Hence, there is still a huge opportunity to develop commercially viable ferrate production technologies capable of producing quantities which will meet water and wastewater treatment sectors cost-effectively.

\section{Electrochemical method for ferrate production}

The last method used to prepare ferrate $(\mathrm{VI})$ salts in this review is the electrochemical process. Through this method, ferrate $(\mathrm{VI})$ salts can be produced by anodic oxidation of iron(II) electrode in an electrolysis cell comprising of a concentrated solution of $\mathrm{KOH}(\mathrm{aq})$ or $\mathrm{NaOH}(\mathrm{aq})[43,45]$. The main cathodic and anodic reactions involved in this method are represented by equations 6-9. 


$$
\begin{aligned}
& \text { Cathodic reaction: } 6 \mathrm{H}_{2} \mathrm{O}_{(\mathrm{aq})}+6 \mathrm{e}^{-} \rightarrow 3 \mathrm{H}_{2(\mathrm{~g})}+6 \mathrm{OH}^{-}(\mathrm{aq}) \\
& \text { Anodic reaction: } \mathrm{Fe}^{2+}{ }_{(\mathrm{aq})}+8 \mathrm{OH}^{-}{ }_{(\mathrm{aq})} \rightarrow \mathrm{FeO}_{4}^{2-}{ }_{(\mathrm{aq})}+4 \mathrm{H}_{2} \mathrm{O}_{(\mathrm{l})}+6 \mathrm{e}^{-} \\
& \text {Overall reaction: } \mathrm{Fe}^{2+}{ }_{(\mathrm{aq})}+2 \mathrm{OH}^{-}{ }_{(\mathrm{aq})}+\mathrm{H}_{2} \mathrm{O}_{(\mathrm{l})} \rightarrow \mathrm{FeO}_{4}^{2-}{ }_{(\mathrm{aq})}+3 \mathrm{H}_{2(\mathrm{~g})} \\
& \text { And: } \mathrm{FeO}_{4}{ }^{2-}{ }_{(\mathrm{aq})}+2 \mathrm{~K}^{+}{ }_{(\mathrm{aq})}\left(\text { or } 2 \mathrm{Na}^{+}\right) \rightarrow \mathrm{K}_{2} \mathrm{FeO}_{4(\mathrm{~s})}\left(\text { or } \mathrm{Na}_{2} \mathrm{FeO}_{4(\mathrm{aq})}\right)
\end{aligned}
$$

The electrochemical synthesis of ferrate $(\mathrm{VI})$ can generate a pure product with respect to other preparation methods. Moreover, the anodic polarisation of the iron electrode in the molten hydroxide is more reasonable when compared to the conventional electrolysis in an aqueous medium since ferrate $(\mathrm{VI})$ is decomposed by water and passivation significantly is reduced in this environment [63]. However, there exists some drawbacks related with electrochemical method of ferrate(VI) salt production, including the production of a residual passive film on the surface of the electrode and the level to which the competitive oxygen evolution reaction is present, at the ferrate( $\mathrm{VI})$ formation potential to room temperature. All of this can decrease the efficiency of the ferrate(VI) synthesis procedure [9]. It also involves high concentrations of electrolytes and can encounter some difficulties with the current. Furthermore, the use of potassium hydroxide for the synthesis of $\mathrm{K}_{2} \mathrm{FeO}_{4}$ and applications in water treatment will also have the same restrictions. The separation of solid or dry $\mathrm{K}_{2} \mathrm{FeO}_{4}$ can also involve several procedures; causing economic disadvantages. However, to reduce the cost of synthesis of ferrate $(\mathrm{VI})$, sodium hydroxide was proposed as the best alkaline medium during this electrochemical method [45]. Electrochemical techniques of ferrate production are still too expensive to produce enough quantities which will meet the needs of water and wastewater treatment sectors.

\section{CHARACTERISATION OF SYNTHESISED FERRATE(VI)}

As usual, once the product is synthesised, it needs to be physically and chemically characterised to confirm if the expected product was formed. However, there are many techniques which are utilised to characterise the produced ferrate $(\mathrm{VI})$ according to its physical and chemical properties [64]. These analytical techniques are described in the following paragraphs.

\section{Quantitative estimation of ferrate(VI)}

Ferrate(VI) may be analysed quantitatively by the methods described in the following subsections.

\section{Volumetric analysis method}

In this method, the prepared ferrate $(\mathrm{VI})$ solution is allowed to oxidise the chromite salt (in excess) as a shown in Equation 10:

$$
\mathrm{FeO}_{4}^{2-}+\mathrm{Cr}(\mathrm{OH})_{4}^{-}+3 \mathrm{H}_{2} \mathrm{O} \rightarrow \mathrm{CrO}_{4}^{2-}+\mathrm{Fe}(\mathrm{OH})_{3}\left(\mathrm{H}_{2} \mathrm{O}\right)_{3}+\mathrm{OH}^{-}
$$

However, the oxidised chromate can be then titrated with an iron(II) salt solution in an acidic medium. The sodium diphenylamine sulfonate can further be served as a suitable indicator $[44,65,66]$. Even if the volumetric analysis technique is used for quantitative analysis of ferrate(VI) salts, degradation of these salts is very rapid in aqueous solution. Thus, phosphate buffer solution is highly needed to keep $\mathrm{pH}$ of the ferrate $(\mathrm{VI})$ solution at 8 . The other biggest disadvantage of this method is that the generated waste needs to be kept and treated before being discarded as it normally produces chromium residual, which is highly a toxic metal for both humans and the environment [44].

The UV-Vis technique also known as a direct colorimetric method is suitable for quantification of 
liquid ferrate $(\mathrm{VI})$ solution. It is founded on determining the concentration of a given solution due to the intensity of the colour absorbed. In the case of ferrate(VI), the characteristic darkish purple colour corresponds to the visible spectrum between 500 and $800 \mathrm{~nm}$ [67]. Bielski and Thomas [68] observed a valuable peak at $510 \mathrm{~nm}$ at pH 10 with a shoulder of 275 and $320 \mathrm{~nm}$. Denvir and Pletcher [69] also reported the absorption spectrum of ferrate $(\mathrm{VI})$ at $505 \mathrm{~nm}$. Two minima of absorbance at 400 and 678 $\mathrm{nm}$ and another absorption shoulder at $570 \mathrm{~nm}$ have been observed [60,70]. The molar absorptivity of ferrate(VI) salt was confirmed to vary between 1150 and $1170 \mathrm{M}^{-1} \mathrm{~cm}^{-1}$, which can help to determine quantitatively the concentration of ferrate $(\mathrm{VI})$ at $\mathrm{pH} 9[44,71]$. Like other methods in analytical chemistry, this method presented some drawbacks because some salts such as barium ferrate(VI) are characterised by low solubility especially in aqueous solution. Moreover, most ferrate(VI) salts tend to decompose in aqueous solution into ferric hydroxides, which can provoke some noise peaks during UV-Vis analysis. This can be avoided by mixing phosphate buffer with ferrate $(\mathrm{VI})$ solution to make complexes with these ferric hydroxides. This technique can also be applied to determine the rate constants of reactions of ferrate(VI) [72].

Indirect method of ferrate(VI) determination using ABTS

Lee, Yoon and von Gunten [72] proposed an indirect method to find out even the lower concentration of ferrate(VI) that can be difficult to measure using 2,2'-azino-bis(3-ethylbenzo-thiazoline-6-sulfonate) (ABTS). However, the colourless ABTS interacts with ferrate $(\mathrm{VI})$ to generate ABTS •+ (a green radical cation of ABTS), which normally shows a representative peak at $415 \mathrm{~nm}[44,72,73]$.

\section{Fourier transform-infrared (FT-IR) spectroscopy}

The FT-IR is a method which is frequently used by many researchers to characterise different ferrate salts in a powder form. It normally uses two types of methods, which are diffuse reflection method and Nujol method. When measuring an infrared spectrum using the diffuse reflection method, the sample powder is normally not measured directly, but diluted in an alkali halide, such as $\mathrm{KBr}$ by forming a sheet that is transparent in the infrared region. For the Nujol method, the sample is distributed in a liquid of approximately equal refractive index, and the infrared spectrum is further measured. Generally, the powder is dispersed in non-volatile liquid paraffin (Nujol) that has low absorption in the infrared region. FT-IR provides a primary peak for ferrate salt around $808 \mathrm{~cm}^{-1}$ and a shoulder peak can also be observed approximately at $780 \mathrm{~cm}^{-1}$, which point out to the asymmetric stretching vibrations of the ironoxygen bond in the ferrate $(\mathrm{VI})$ compound [74]. The more the intensity of the characteristic vibrational peak of ferrate $(\mathrm{VI})$ is strong, more the purity of the prepared ferrate $(\mathrm{VI})$ is also higher. FT-IR can also be used to study the structures of degraded pollutants after being exposed to ferrate as an oxidant [8].

\section{Scanning electron microscopic study}

The Scanning electron microscopy (SEM) is currently used to characterise the ferrate(VI) salts in the powder form by providing some micrographs or structural images of the product. For example, Lei, Zhou, Cheng \& Du [60] characterised the potassium ferrate(VI) using the SEM analysis where the crystals obtained were plump, columnar and had cone-shaped growth surface at the two ends of the crystalline grains.

\section{$X-R a y$ powder Diffraction (XRD) method}

The XRD is another method which goes together with FT-IR and SEM analyses in order to confirm the crystallinity, structures and magnetic properties of the ferrate $(\mathrm{VI})$ salts. The $\mathrm{XRD}$ is one of the analytical facilities used to indicate the presence of ferrate(VI) by demonstrating the isomorphism with other ferrate salts obtained in the literature [45,60]. For example, in the study conducted by Lei, Zhou, Cheng and Du [60], their XRD pattern results indicated an orthorhombic crystal structure of ferrate(VI) salt. 


\section{Mössbauer spectroscopy}

Mössbauer spectroscopy allows detecting the oxidation state of iron. Thus, it can help to determine the degradation rate of $\mathrm{Fe}(\mathrm{VI})$ in ferrate $(\mathrm{VI})$ ion over time. It also helps to check the presence of a magnetic order at low temperature [44,45].

\section{STABILITY STUDIES OF FERRATE(VI) SALTS}

Stability of ferrate(VI) solution depends on factors such as coexisting ions in the solution, temperature, $\mathrm{pH}$ and concentration of the solution. About the temperature of the solution, research showed that are more stable at a low temperature approximately at $0.5^{\circ} \mathrm{C}$. For example, a solution of $0.01 \mathrm{M}$ ferrate $(\mathrm{VI})$ remained almost unaffected for a period of 2 hours at $0.5^{\circ} \mathrm{C}$ while a reduction of $10 \%$ was observed when was increased to $25^{\circ} \mathrm{C}$ [75]. About the concentration of the solution, studies revealed that highly concentrated solutions of ferrate $(\mathrm{VI})$ are unstable compared to their serial dilutions. For conservation or coexistence of ions and $\mathrm{pH}$ of the solution, coexistence of ions such as $\mathrm{Fe}^{2+}, \mathrm{Mn}^{2+}, \mathrm{CO}_{3}{ }^{2-}$ has been reported to affect the stability of $\mathrm{Fe}(\mathrm{VI})$ in previous studies and spontaneous decomposition was shown to be directly proportional to the decrease of $\mathrm{pH}$ value [55]. Phosphate buffer solution and high concentration of potassium hydroxide (more than $10 \mathrm{M}$ ) were found to retard the ferrate $(\mathrm{VI})$ degradation. Nitrate ions and diatomite can also be used for the conservation of ferrate(VI) salts [75]. In another study, sodium ferrate $(\mathrm{VI})$ in $50 \%$ of sodium hydroxide degrades gradually at ambient temperature and can be preserved with slight degradation for a period of one month at $0^{\circ} \mathrm{C}[76]$. Solid ferrate(VI) salts showed to be more stable compared to their dissolved derivatives. Due to its high stability, dry potassium ferrate(VI) at temperature below $198^{\circ} \mathrm{C}$ can be used to prepare other ferrate(VI) salts such as silver, strontium and barium ferrate(VI) salts [77]. Despite these factors that can affect the stability of ferrate(VI), some preparation methods can conduct to an unstable product. Wet oxidation method is the one showed to be more successful and practical compared to electrochemical and dry methods, but it also showed some weaknesses of generating an unstable ferrate $(\mathrm{VI})$ product as the reaction occurs in the aqueous medium. In-situ electrochemical synthesis of ferrate(VI) can be also a reliable technique for getting a more stable product. In the study conducted by Panagoulopoulos [78] at the University of Surrey to assess the performance of $\mathrm{K}_{2} \mathrm{FeO}_{4}$ in water and wastewater treatment, conservation conditions showed that light has no effect on the stability of ferrate $(\mathrm{VI})$ solutions.

\section{APPLICATION OF FERRATE(VI) SALTS}

The ability of ferrate $(\mathrm{VI})$ to act as a disinfectant, flocculant, oxidant, and coagulant makes it more attractive than other existing chemicals currently being applied in water and wastewater treatments such as aluminum sulphate, ferric chloride, potassium permanganate and chromium trioxide. However, using ferrate $(\mathrm{VI})$ as a multipurpose chemical offers several advantages such as reduction of cost for treatment due to coagulating and oxidising properties in a single dosing and mixing unit and generating environmentally friendly by-products $[58,79]$. For example, De Luca et al. [80] compared the coagulating activities of ferrate $(\mathrm{VI})$ to alum, and their results showed that ferrate $(\mathrm{VI})$ removed the higher percentage of bromodichloromethane, 1,2-dichlorobenzene, naphthalene, and trichloroethylene when coupled with paddle or gas flocculation than alum. Two oxidation methods, viz., Fenton's reagent and ferrate(VI), treating mature leachate containing organic material such as humic substances from landfills were also compared in another similar study conducted by Batarseh et al. [81]. Fenton's reagent is also known as a powerful AOP, which uses hydrogen peroxide and iron(II) to generate the hydroxyl-free radical. Like ferrate $(\mathrm{VI})$, Fenton's reagent may also act as a coagulant because of the ferrous iron generated through its sequestration. However, both oxidation methods were found to remove organic materials through physical and chemical processes. Even if Fenton's reagent reduced dissolved organic carbon (DOC) and chemical oxygen demand (COD) more than ferrate(VI) and generated more readily biodegradable by-products (BBPs), ferrate(VI) was more advantageous because it was active over a wider $\mathrm{pH}$ range [81]. The lower the $\mathrm{pH}$, the greater removal of organic compounds revealing the strong 
capacity of ferrate $(\mathrm{VI})$ to work in the acidic medium. Both processes reduced leachate organic content to acceptable release limits. However, the Fenton's reagent could be utilised as a pre-treatment to biological treatment while ferrate $(\mathrm{VI})$ should be used where BBPs are not required [81]. Ferrate $(\mathrm{VI})$ has also been applied to oxidise different pollutants such as sulphur- and nitrogen-containing compounds [21]. Results showed that the reaction between ferrate $(\mathrm{VI})$ and sulphur or nitrogen-containing pollutants followed the first-order reaction kinetics with the reaction rate increasing with a decrease in $\mathrm{pH}$ values. At stoichiometric values, ferrate $(\mathrm{VI})$ was able to oxidise hydrogen thiocyanate, thioacetamide, sulphide, thiourea, and cyanide to non-hazardous by-products. Ferrate(VI) also sequestrates into ferric ions in an aqueous medium, another harmless by-product which can further be used in the coagulation processes $[24,50,79,82]$. During coagulation, the floc size is larger when applying ferrate( $\mathrm{VI})$ as opposed to alum, suggesting that a ferrate $(\mathrm{VI})$ is a better coagulant because of reduced turbidity observed in highly organic waters $[22,41]$. When used as a disinfectant, studies have shown that ferrate(VI) salt is more effective than chlorine in reducing different types of bacteria and viruses $[37,78]$. Furthermore, ferrate(VI) has been used to control odour, to remove pharmaceutical pollutants such as amoxicillin, ciprofloxacin, 2,4-dichlorophenoxyacetic acid, and flurbiprofen from wastewater [74], to stabilise and dewater primary sludge [83], and to remove freshwater humic substances from water [84].

Interest has also been focused on the reaction of ferrate(VI) salts with several organic contaminants. For example, Waite and Gilbert [85] studied the impact of ferrate(VI) on benzene, toluene, xylene, chlorobenzene, nitrobenzene, aniline, allylbenzene, and phenol. Phenol and naphthalene were also $100 \%$ degraded during a study performed by De Luca et al. [86]. Trichloroethylene was also significantly degraded at $96.2 \%$. Graham et al. [87] found the decomposition of phenol by ferrate(VI) ion at a molar ratio of $5: 1$ [ferrate $(\mathrm{VI})$ : phenol] to be greatest at $\mathrm{pH}$ 9.2. The degradation greatly decreased to a $\mathrm{pH}$ of 11 due to the low reactivity of ferrate $(\mathrm{VI})$. Very different outcomes were obtained for the reaction between ferrate $(\mathrm{VI})$ and 2,4- trichlorophenol (TCP). The $\mathrm{pH}$ range for the highest decay was 5.8-7.0. Above 7, the degradation of TCP decreased progressively. The molar ratio of 5:1 again gave the highest percentage degradation around $87 \%$. Recently, Sun et al. [88] also produced ferrate(VI) solution using the electrochemical method and this has been used to decompose phenol in water at two concentration levels ( 2 and $5 \mathrm{ppm}$ ). The maximum degradation efficiency was approximately $70 \%$ and the optimum $\mathrm{pH}$ for phenol treatment was 9.0 [88]. Experimental studies conducted by treating phenol using other predictable coagulants such as polyaluminum chloride (PAC) and ferric chloride revealed that the elimination of phenol by ferrate(VI) occurred mostly by oxidative conversion [88]. In another study, the removal of fulvic acids (FA) and humic substances (HS) with ferrate(VI) has also created attention because of its coagulating and oxidising properties. The proper dose of ferrate $(\mathrm{VI})$ and the $\mathrm{pH}$ of the reaction between ferrate( $\mathrm{VI})$ and $\mathrm{HS}$ or FA were optimised [24]. The ferrate(VI) dosages ranged from 0 to $20 \mathrm{ppm}$ and the $\mathrm{pH}$ values tested were 4, 5, 6 and 8. The effectiveness of ferrate (VI) was tested against the performance of ferric sulphate (FS) to reduce the compounds listed above [89]. Ferrate(VI) performed better than $\mathrm{FS}$ at removing $\mathrm{DOC}$ at $\mathrm{pH} 6$ and 8, and a dosing range of 2-12 ppm as Fe. Over a dosing range of 2-14 ppm as $\mathrm{Fe}$ with the same values of $\mathrm{pH}$, ferrate $(\mathrm{VI})$ also removed more UV 254-absorbing compounds. Ferrate(VI) was successful at removing colour at all $\mathrm{pH}$ ranges and at dosages of $6 \mathrm{ppm}$ or greater [89]. At low dosages, ferrate $(\mathrm{VI})$ was superior to FS for preventing THM formation. Although, at higher dosages of ferrate(VI), THM formation increased, while for FS, the THM formation remained constant [89]. The above results showed that ferrate(VI) was superior to FS in eliminating natural organic matter, which can produce DBPs when reacting with chlorine. The study of Cooley [89] also compared the capacity of ferrate(VI), chlorine, aluminum sulphate (AS), and FS in inactivation of $E$. coli, removal of total $\mathrm{COD}$ and dissolved COD. Ferrate(VI) required a much lower dosage requirement of $6 \mathrm{ppm}$ as Fe to inactivate $100 \% \mathrm{E}$. coli, while $\mathrm{FS}$ with chlorine required either 4 or $8 \mathrm{ppm}$ as $\mathrm{Fe}$, and 10 or 8 ppm as chlorine, respectively. Lastly, less sludge was produced, while more pollutants were removed, when ferrate $(\mathrm{VI})$ was used as a coagulant. The same concentrations of AS and FS were used as ferrate $(\mathrm{VI})$, in millimoles as aluminum or iron, respectively. At lower dosages, 
ferrate(VI) still generated less sludge and removed more pollutants [89]. These experimental studies further confirmed that ferrate $(\mathrm{VI})$ can be applied as a disinfectant, oxidant and coagulant of wastewater and water treatment. Decomposition of benzothiophene (BT) in an aqueous medium by $\mathrm{K}_{2} \mathrm{FeO}_{4}$ was also investigated $[90,91]$. The decomposition efficiency of BT has been recorded at several values of $\mathrm{pH}$ and ferrate $(\mathrm{VI})$ dosages at a fixed initial concentration of $\mathrm{BT}$. This BT was removed promptly within 30 seconds by $\mathrm{K}_{2} \mathrm{FeO}_{4}$ while the highest decomposition efficiency was reached at $\mathrm{pH} 5$ and the lowest one at $\mathrm{pH}$ 9. Similarly, the initial rate constant of BT increased with the decreasing of the initial concentration of BT [92]. Lee and Tiwari [92] used ferrate(VI) to remove $\mathrm{Ni}, \mathrm{Cu}$ and $\mathrm{Cu}-\mathrm{Ni}$ cyanide complexes in an effort to deal with metal-complexed cyanide wastes. On one hand, for $\mathrm{Ni}$ and $\mathrm{Cu}$ cyanide system, a fast and productive oxidation of cyanide ion happened at $\mathrm{pH} 10$ in these complexes; almost a complete $\mathrm{Cu}$ removal was relatively reached at $\mathrm{pH} 13$. On the other hand, Ni concentration was only attenuated at $\mathrm{pH} 10$ through precipitation process and then decreased when $\mathrm{pH}$ increased to 13 [92]. Comparable results were also detected in Cu-Ni cyanide complex, where a complete removal of $\mathrm{Cu}$ and $\mathrm{CN}$ was attained treating with ferrate $(\mathrm{VI})$ while Ni was partially eliminated. Li, Wang, Liu and Zhang [5] and Lee, Um and Yoon [10] investigated the oxidising ability of the $\mathrm{K}_{2} \mathrm{FeO}_{4}$, ferrate(VI)hypochlorite liquid mixture and $\mathrm{KMnO}_{4}$ by decolourising the azo dye Orange II. However, $\mathrm{K}_{2} \mathrm{FeO}_{4}$ showed to be more effective than $\mathrm{KMnO}_{4}$ while the ferrate $(\mathrm{VI})$-hypochlorite liquid mixture containing a residual hypochlorite was even more effective whether the low dosage of ferrate(VI) solution or high concentration of dye was used. The initial $\mathrm{pH}$ of the solution had little influence on the colour elimination by the ferrate(VI)-hypochlorite liquid mixture. $\mathrm{KMnO}_{4}$ was also applied to degrade an Active Brillant Red X-3B ( $9 \%$ of TOC and $42 \%$ of COD and $99 \%$ of colour removal) [93] and for wastewater treatment comprising anthraquinone and azo dyes (colour removal of 87\%) [13]. Additionally, the oxidation ability of ferrate( $\mathrm{VI})$ to remove various pollutants in water and wastewater has been established [44]. These pollutants include thiocyanates, sulphides, ammonia, metal cyanide complexes, iodides, heavy metals, carbohydrates, cycloalkanes, toluene, alcohols, ketones, phenols, aminobenzene, emerging micropollutants such as pharmaceutical and personal care products (PPCPs) and endocrine disrupting chemicals (EDCs), triclosan and benzotriazoles. Among these environmental pollutants, ferrate(VI) showed to be very effective in the removal of arsenic species from water at a comparatively low concentration level (2 ppm) [44,92,94-96]. Moreover, the combined application of low concentration of ferrate $(\mathrm{VI})$ (below $0.5 \mathrm{ppm}$ ) and $\mathrm{Fe}(\mathrm{III})$ as the main coagulant agent was found to be an effective process for the arsenic removal. Pharmaceuticals in water and wastewater treatment processes, including photo-catalytic degradation, ozonation and other AOPs have been explored by several researchers [74]. Lately, ferrate $(\mathrm{VI})$ has been studied widely, as it could be an effective alternative to conventional AOPs for the degradation of pharmaceutical pollutants. Ferrate $(\mathrm{VI})$ has many benefits due to its oxidising and coagulating properties. Thus, ferrate $(\mathrm{VI})$ is likely to be one of the most useful and multifunction chemicals in water and wastewater treatments. Ferrate $(\mathrm{VI})$ has been applied in the breakdown of $\mathrm{N}$-nitrosodimethylamine (NDMA) from aqueous media under the simulated batch reactor (SBR) operations [29]. The degradation of NDMA was followed by the second-order rate constant at a wide $\mathrm{pH}$ range of 6-12 [97]. A $\beta$ - blocker propranolol was also treated with ferrate(VI) in the SBR system [98]. A preliminary but useful study was conducted for the detection and treatment of ciprofloxacin from wastewaters. It was found that ferrate(VI) enabled to remove more than $60 \%$ of ciprofloxacin and this was even increased at higher concentrations of ferrate( $\mathrm{VI})$, that is, at 1 ppm [96]. The 5-chloro-2-[2,4dichlorophenoxy]-phenol with commercial name of Triclosan, which is an antimicrobial agent and extensively used as PCPs, seemingly enters into the aquatic environment was treated with ferrate( $\mathrm{VI})$ at $\mathrm{pH}$ ranging between 7 and 10 . The overall apparent rate constant was found to be $746 \mathrm{M}^{-1} \mathrm{~s}^{-1}$ at $\mathrm{pH}$ 7.0 and a complete decomposition was reached at the ferrate( $\mathrm{VI})$ to pollutant ratio of 10:1 [94]. Bisphenol-A (BPA) was degraded slightly at acidic conditions $\mathrm{pH}$ range of 5-6 and showed that about $50 \%$ of BPA was apparently mineralised at the ferrate(VI)/BPA molar ratio $4: 1$. It was also confirmed that the oxidation of BPA was suppressed in the presence of metasilicate, humic acid and tert-butanol, 
whereas the oxidation of BPA was further increased in the presence of hydrogen carbonate ions [99]. A more descriptive study was also conducted in the oxidative removal of other EDCs, namely: $17 \alpha$-ethynylestradiol (EE2), estriol (E3), $\beta$-estradiol (E2), and estrone (E1) at a pH range 8 to 12 [44,95]. The results indicated that ferrate $(\mathrm{VI})$ was more reactive at lower $\mathrm{pH}$ conditions and also followed secondorder rate kinetics in the degradation of these pollutants [100]. These studies confirmed that ferrate(VI) is a strong oxidant for efficient degradation of water emerging micropollutants such as PCPs and EDCs as well as pharmaceuticals. Other studies also demonstrated that ferrate(VI) is a useful oxidant in the degradation of several metal-complexed species, organic and inorganic pollutants and the sequestrated ferrate(VI) into iron(III) enabled to remove significantly the free metallic impurities by coagulation process [92,101,102]. Also, all advantages and disadvantages of using ferrate(VI) as oxidant and disinfectant are shown in Table I.

Table I. Advantages and disadvantages of using different current oxidants and disinfectants

\begin{tabular}{|c|c|c|}
\hline $\begin{array}{l}\text { Oxidant and } \\
\text { disinfectant }\end{array}$ & Advantages & Disadvantages \\
\hline \multirow[t]{4}{*}{ Chlorine } & \multirow{4}{*}{$\begin{array}{l}\text {-Low cost } \\
\text {-High removal efficiency } \\
\text {-Availability } \\
\text {-The possibility of long-term storage } \\
\text { of chlorine in cylinders }\end{array}$} & -The possibility of producing dangerous by- \\
\hline & & products such as three halomethanes \\
\hline & & -Toxicity for water and sewage treatment plant \\
\hline & & $\begin{array}{l}\text {-The need to dechlorinate treated wastewater } \\
\text { before releasing into environment }\end{array}$ \\
\hline \multirow[t]{5}{*}{ Ozone } & $\begin{array}{l}\text {-High capacity and high speed of } \\
\text { oxidation and disinfection }\end{array}$ & $\begin{array}{l}\text {-Possibility of remaining few cysts and viruses } \\
\text { after disinfection process }\end{array}$ \\
\hline & $\begin{array}{l}\text {-Converting of ozone to oxygen } \\
\text { after disinfection process }\end{array}$ & $\begin{array}{l}\text {-Oxidation by ozone requires complex } \\
\text { equipment }\end{array}$ \\
\hline & -Non-toxic by-products & -The high price of ozone production \\
\hline & \multirow[t]{2}{*}{-Ability of odour and taste removal } & -Producing of solid by-products \\
\hline & & $\begin{array}{l}\text {-Corrosion in the equipment of water and } \\
\text { wastewater treatment }\end{array}$ \\
\hline \multirow[t]{8}{*}{ Ferrate(VI) } & \multirow{2}{*}{$\begin{array}{l}\text {-Excessive capacity of oxidation } \\
\text { and disinfection }\end{array}$} & -Low ferrate( $(\mathrm{VI})$ production rate \\
\hline & & -Lack of stability for long-term storage \\
\hline & -Non-toxic by-products & \\
\hline & $\begin{array}{l}\text {-Ability of colloidal particles } \\
\text { coagulation }\end{array}$ & \\
\hline & $\begin{array}{l}\text {-Ability of coagulation, oxidation and } \\
\text { disinfection simultaneously }\end{array}$ & \\
\hline & $\begin{array}{l}\text {-Needing smaller wastewater } \\
\text { treatment plant }\end{array}$ & \\
\hline & -Low application cost & \\
\hline & $\begin{array}{l}\text {-Ability of heavy metal and inorganic } \\
\text { removal }\end{array}$ & \\
\hline
\end{tabular}

\section{CONCLUSION}

This review found that ferrate $(\mathrm{VI})$ salts are currently applied in water and wastewater treatment processes at piloting levels due to their strong oxidising, disinfecting, flocculating and coagulating tendencies. The reviewed studies also indicated that ferrate $(\mathrm{VI})$ can remove bacteria, partially or totally 
oxidise or degrade inorganic and organic pollutants, emerging micropollutants such as EDCs, PPCPs, illicit drugs, reduce or completely precipitate suspended particulate materials, metals, and metalcomplexed species in a single mixing and dosing unit. Other studies also demonstrated that ferrate( $\mathrm{VI})$ is a useful coagulating agent as the sequestrated ferrate(VI) into iron(III) (environmentally-friendly ferricbased compounds) enabled to remove significantly free metallic impurities through coagulation and sedimentation processes. Under acidic conditions, the oxidation potential of the ferrate(VI) salts is higher than any other oxidant that can be applied in water and wastewater treatment processes. Regardless of several valuable properties in environmental studies, ferrate(VI) continued to be unavailable on the market due to the high cost of production and chemical instability. Three promising methods for manufacturing liquid of solid ferrate $(\mathrm{VI})$ were also identified in this review, namely: wet chemical oxidation method, dry method and electrochemical method. For this reason, several studies have been conducted to explore its effective application in full-scale water and wastewater treatments. Stability of ferrate $(\mathrm{VI})$ solution depends on many factors such as coexisting ions in the solution, temperature, $\mathrm{pH}$ and concentration. For temperature of the solution, research showed that ferrate $(\mathrm{VI})$ salts are more stable at low temperature approximately at $0.5^{\circ} \mathrm{C}$. Phosphate buffer solution and high concentration of potassium hydroxide (more than $10 \mathrm{M}$ ) were found to retard or decline the ferrate(VI) degradation. Nitrate ions and diatomite can also be used for the conservation of ferrate( $\mathrm{VI})$ salts. In another study, sodium ferrate $(\mathrm{VI})$ in $50 \%$ of sodium hydroxide degrades gradually at ambient temperature and can be preserved with slight degradation for a period of one month at $0{ }^{\circ} \mathrm{C}$. Solid ferrate $(\mathrm{VI})$ salts showed to be more stable compared to their dissolved derivatives. Wet oxidation method is the one showed to be more successful and practical compare to electrochemical and dry methods, but it also showed some weaknesses of generating an unstable ferrate $(\mathrm{VI})$ product as the reaction occurs in the aqueous medium. To avoid this, washing and drying of the final product can direct to the stable ferrate( $\mathrm{VI})$. Insitu electrochemical preparation of ferrate $(\mathrm{VI})$ can also be a reliable technique for getting a more stable product. Lastly, conservation conditions showed that light has no effect on the stability of ferrate(VI) solutions.

\section{Recommendations}

Much work has been done on water and wastewater treatment by removing, degrading, disinfecting, and oxidising different inorganic and organic pollutants as well as emerging micropollutants, but a few works have been done on removing metals from wastewater as well as for acid mine drainage (AMD) using ferrate $(\mathrm{VI})$ salts. The authors recommend also to apply these ferrate $(\mathrm{VI})$ salts in $\mathrm{AMD}$ treatment as they can work as a powerful disinfectant, coagulant and oxidant in order to reduce the energy consumption during aeration and pumping, and prevent generation of toxic by-products currently encountered during the AMD treatment. Self-decomposition of ferrate(VI) salts provides ferric ions in the solution and latter can be used to remove sulphates and other metal ions through co-precipitation and coagulation processes.

\section{Acknowledgement}

This work has been financially supported by the Faculty of Science, University of Johannesburg, South Africa. The authors would like also to thank the group members from the LAB 3404 and Prof. Philiswa N. Nomngongo, Doornfontein Campus, University of Johannesburg, South Africa.

Manuscript received: June 4, 2019; revised manuscript received: August 26, 2019; manuscript accepted: October 3, 2019; published online: October 18, 2019. 


\section{REFERENCES}

1. Parać, P. Conventional and non-conventional wastewater treatment plants: advantages and disadvantages. Doctoral thesis, 2015, Math Science College, Biological Department, Zagreb University, Croatia.

2. Chandran, D. Int J Sci Eng Res., 2016, 7 (1), pp 392-403 (https://www.ijser.org/researchpaper/areview-of-the-textile-industries-waste-water-treatment-methodologies.pdf).

3. Matin, A. R.; Yousefzadeh, S.; Ahmadi, E.; Mahvi, A.; Alimohammadi, M.; Aslani, H.; Nabizadeh, R. Food Chem Toxic., 2018, 116, pp 129-137 (https://doi.org/10.1016/j.fct.2018.04.002).

4. Martınez, N. S. S.; Fernández, J. F.; Segura, X. F.; Ferrer, A. S. J Hazard Mater., 2003, 101 (3), pp 315-322 (https://doi.org/10.1016/S0304-3894(03)00207-3).

5. Li, G.; Wang, N.; Liu, B.; Zhang, X. Desalination, 2009, 249 (3), pp 936-941 (https://doi. org/10.1016/j.desal.2009.06.065).

6. Płonka, I.; Pieczykolan, B.; Barbusiński, K.; Kalka, J.; Thomas, M.; Piskorz, P.J. Fibres \& Textiles in Eastern Europe, 2017, 25 (6(126)) (http://dx.doi.org/10.5604/01.3001.0010.5379).

7. Brandt, M. J.; Johnson, K. M.; Elphinston, A. J.; Ratnayaka, D. D. Chemistry, Microbiology and Biology of Water. In: Twort's Water Supply, Chapter 7. Butterworth-Heinemann, Oxford, 2017, pp 235-321.

8. Ciabatti, I.; Tognotti, F.; Lombardi, L. Desalination, 2010, 250 (1), pp 222-228 (https://doi. org/10.1016/j.desal.2009.06.019).

9. Sharma, V. K. US 8961921 B2, 2015, Florida Institute of Technology Inc.

10. Lee, Y.; Um, I. H.; Yoon, J. Environ Sci \& Tech., 2003, 37 (24), pp 5750-5756 (https://doi. org/10.1021/es034203+).

11. Mukattash, A. Comparison of the formation during disinfection: ferrate versus free chlorine for different source waters. Master's thesis. 2007. University of Central Florida, USA.

12. Novak, P.; Kolar, M.; Machala, L.; Siskova, K. M.; Karlicky, F.; Petr, M.; Zboril, R. Chem. Phys., 2018, 20 (48), pp 30247-30256 (https://doi.org/10.1039/C8CP05952G).

13. Mosivand, S.; Kazeminezhad, I. J Mat Sci: Mat Electron., 2018, 29 (14), pp 1-11 (https://doi. org/10.1007/s10854-018-9365-9)

14. Trang, N. T. T.; Thy, L. T. M.; Cuong, P. M.; Tu, T. H.; Hieu, N. H. In AIP Conference Proceedings. 2018, 1954 (1), p 040001 (https://doi.org/10.1063/1.5033401).

15. Terryn III, R. J.; Huerta-Aguilar, C. A.; Baum, J. C.; Sharma, V. K. Chem Eng J., 2017, 330, pp 1272-1278 (https://doi.org/10.1016/j.cej.2017.08.080).

16. Schmidbaur, H. Z. Anorg. Allg. Chem., 2018, 644 (12-13) pp 536-559 (https://doi.org/10.1002/ zaac.201800036).

17. Jiang, J. Q.; Lloyd, B. Water Res., 2002, 36 (6), pp 1397-1408 (https://doi.org/10.1016/S00431354(01)00358-X).

18. Qu, J. H.; Liu, H. J.; Liu, S. X.; Lei, P. J. J Environ Eng., 2003, 129 (1), 17-24 (https://doi. org/10.1061/(ASCE)0733-9372(2003)129:1(17)).

19. Sharma, V. K.; Li, X. Z.; Graham, N.; Doong, R. A. J Water supply: Res and Tech-AQUA, 2008, 57 (6), pp 419-426 (https://doi.org/10.2166/aqua.2008.077).

20. Sharma, V. K. Adv in Environ Res., 2002, 6 (2), pp 143-156 (https://doi.org/10.1016/S10930191(01)00119-8).

21. Sharma, V. K. Water Sci and Tech., 2004, 49 (4), pp 69-74 (https://doi.org/10.2166/ wst.2004.0223).

22. Sharma, V. K.; Kazama, F.; Jiangyong, H.; Ray, A. K. J Water and Heal., 2005, 3 (1), pp 45-58 (https://doi.org/10.2166/wh.2005.0005.)

23. Tiwari, D.; Yang, J. K.; Lee, S. M. Eng Res., 2005, 10 (6), pp 9-282 (https://doi.org/10.4491/ eer.2005.10.6.269) 
24. Jiang, J. Q.; Wang, S.; Panagoulopoulos, A. Chemosphere, 2006, 63 (2), pp 212-219 (https://doi. org/10.1016/j.chemosphere.2005.08.020).

25. Jiang, J. Q. J Hazard Mater., 2007, 146 (3), pp 617-623 (https://doi.org/10.1016/j.jhazmat.2007.04.075).

26. Yngard, R.; Damrongsiri, S.; Osathaphan, K.; Sharma, V. K. Chemosphere, 2007, 69( 5), pp 729735 (https://doi.org/10.1016/j.chemosphere.2007.05.017).

27. Al Rahman, M. A.; Hassan, A. A.; Mohamed, G. G.; Remon, E. M. Procedia Environ Sci., 2016, 34, pp 285-297 (https://doi.org/10.1016/j.proenv.2016.04.026).

28. Sharma, V. K. J Environ Sci and Heal Part A, 2010, 45 (6), pp 645-667 (https://doi. org/10.1080/10934521003648784).

29. Sailo, L.; Tiwari, D.; Lee, S. M. Sep Sci and Tech., 2017, 52 (17), pp 2756-2766 (https://doi.org/10. 1080/01496395.2017.1374976).

30. Jiang, J. Q. J Chem Tech \& Biotech., 2014, 89 (2), pp 165-177 (https://doi.org/10.1002/jctb.4214).

31. Boorman, G. A. Environ Heal Per., 1999. 107 (1), pp 207-217 (https://doi.org/10.1289/ ehp.99107s1207)

32. How, Z.T. Reaction Pathways in the Chlorination of Amino Acids. Doctoral thesis, 2016, Curtin University, Australia.

33. Richardson, S. D. TrAC Tr in Anal Chem., 2003, 22 (10), pp 666-684 (https://doi.org/10.1016/ S0165-9936(03)01003-3).

34. Sharma, V. K.; Luther III, G. W.; Millero, F. J. Chemosphere, 2011, 82 (8), pp 1083-1089 (https:// doi.org/10.1016/j.chemosphere.2010.12.053).

35. Golovko, D. A.; Sharma, V. K.; Suprunovich, V. I.; Pavlova, O. V.; Golovko, I. D.; Bouzek, K.; Zboril, R. Anal Letters, 2011, 44 (7), pp 1333-1340 (https://doi.org/10.1080/00032719.2010.511748).

36. Han, Q.; Wang, H.; Dong, W.; Liu, T.; Yin, Y. Sep and Purif Tech., 2013, 118, pp 653-658 (https:// doi.org/10.1016/j.seppur.2013.07.042).

37. Zhou, S.; Shao, Y.; Gao, N.; Zhu, S.; Li, L.; Deng, J.; Zhu, M. Chem Eng J., 2014, 251, pp 304-309 (https://doi.org/10.1016/j.cej.2014.04.081).

38. Machala, L.; Zboril, R.; Sharma, V. K.; Filip, J.; Schneeweiss, O.; Homonnay, Z. J Phys Chem B., 2007, 111 (16), pp 4280- 4286 (https://doi.org/10.1021/jp068272x).

39. Sharma, V. K., Water Sci \& Tech., 2007, 55 (https://doi.org/10.2166/wst.2007.019).

40. Jiang, J. Q. Procedia Environ Sci., 2013, 18, pp 418-426 (https://doi.org/10.1016/j. proenv.2013.04.056).

41. Ma, J.; Liu, W. Water Res., 2002, 36 (4), pp 871-878 (https://doi.org/10.1016/S00431354(01)00282-2).

42. Jiang, J. Q.; Durai, H. B.; Petri, M.; Grummt, T.; Winzenbacher, R. Desalination and Water Treat., 2016, 57 (54), pp 26369-26375 (https://doi.org/10.1080/19443994.2016.1203825).

43. Alsheyab, M.; Jiang, J. Q.; Stanford, C. J Environ Man., 2009, 90 (3), pp 1350-1356 (https://doi. org/10.1016/j.jenvman.2008.10.001).

44. Tiwari, D.; Lee, S. M. Ferrate (VI) in the treatment of wastewaters: a new generation green chemical. In: Einschlag, F. S. G. (Ed.) Waste Water-Treatment and Reutilization. InTech, Rijeka, Croatia, 2011, Chapter 12, p 241.

45. El Maghraoui, A.; Zerouale, A.; ljjaali, M.; Sajieddine, M. Adv Mat Phys Chem., 2013, 3 (01), p 83 (http://dx.doi.org/10.4236/ampc.2013.31013).

46. Stanford, C.; Jiang, J. Q.; Alsheyab, M. Water, Air, \& Soil Pollut., 2010, 209 (1-4), pp 483-488 (https://doi.org/10.1007/s11270-009-0216-4)

47. Talaiekhozani, A.; Bagheri, M.; Talaei, M. R.; Jaafarzadeh, N. Jundishapur J Heal Sci., 2016, 8 (3) (http://dx.doi.org/10.17795/jjhs-34904).

48. Gump, J. R.; Wagner, W. F.; Schreyer, J. M. Anal Chem., 1954, 26 (12), pp 1957-1957 (https://doi. org/10.1021/ac60096a027).

49. Herber, R. H.; Johnson, D. Chemistry, 1979, 18 (10), pp 2786-2790 (https://doi.org/10.1021/ic50200a030). 
50. Neveux, N.; Aubertin, N.; Gerardin, R.; Evrard, O. In: Klute, R.; Hahn, H. H. (Eds) Chemical Water and Wastewater Treatment III. Springer, Berlin, Heidelberg, 1994, pp 95-103 (https://doi. org/10.1007/978-3-642-79110-9_7).

51. Dedushenko, S. K.; Perfiliev, Y. D.; Golubev, A. M.; Melnikov, P.; Corbi, P. P.; Saprykin A. A. In: Thomas M. F.; Williams J. M.; Gibb T. C. (Eds) Hyperfine Interactions (C). Springer, Dordrecht. 2002, pp 277-280 (https://doi.org/10.1007/978-94-010-0281-3_69).

52. Thompson, G. W.; Ockerman, L.; Schreyer, J. M. J A Chem Soc., 1951, 73 (3), pp 1379-1381 (https://doi.org/10.1021/ja01147a536).

53. White, D. A.; Franklin, G. S. Environ Tech., 1998, 19 (11), pp 1157-1161 (https://doi. org/10.1080/09593331908616776).

54. Bouzek, K.; Flower, L.; Roušar, I.; Wragg, A. A. J App Electrochem., 1999, 29 (5), pp 569-576 (https://doi.org/10.1023/A:1026491704787).

55. Li, C.; Li, X. Z.; Graham, N. Chemosphere, 2005, 61 (4), pp 537-543 (https://doi.org/10.1016/j. chemosphere.2005.02.027)

56. Tiwari, D.; Kim, H. U.; Choi, B. J.; Lee, S. M.; Kwon, O. H.; Choi, K. M.; Yang, J. K. J Environ Sci and Heal, Part A, 2007, 42 (6), pp 803-810 (https://doi.org/10.1080/10934520701304674).

57. Ghernaout, D.; Naceur, M. W. Des and Water Treat., 2011, 30 (1-3), pp 319-332 (https://doi. org/10.5004/dwt.2011.2217).

58. Talaiekhozani, A.; Bagheri, M.; Goli, A.; Khoozani, M. R. T. J Environ Man., 2016, 170, pp 186-206 (https://doi.org/10.1016/j.jenvman.2016.01.021).

59. Lee, Y.; Kissner, R.; von Gunten, U. Environ Sci \& Tech., 2014, 48 (9), pp 5154-5162 (https://doi. org/10.1021/es500804g).

60. Lei, B.; Zhou, G.; Cheng, T.; Du, J. Asian J Chem., 2013, 25(1) (https://doi.org/10.14233/ ajchem.2013.11685)

61. Evrard, O. J.; Gerardin, R. A.; Schmitt, N.; Evrard, J. L. US5284642A, 1994, Centre International de l' Eau de Nancy (NANCIE).

62. Kanari, N.; Ostrosi, E.; Ninane, L.; Neveux, N.; Evrard, O. JOM, 2005, 57 (8), pp 39-42 (https://doi. org/10.1007/s11837-005-0166-2).

63. Híveš, J.; Benová, M.; Bouzek, K.; Sharma, V. K. Electrochem Comm., 2006, 8 (11), pp 17371740 (https://doi.org/10.1016/j.elecom.2006.08.002).

64. Wei, Y. L.; Wang, Y. S.; Liu, C. H. Metals, 2015, 5 (4), pp 1770-1787 (https://doi.org/10.3390/ met5041770).

65. Licht, S.; Naschitz, V.; Liu, B.; Ghosh, S.; Halperin, N.; Halperin, L.; Rozen, D. J Pow Sour., 2001, 99 (1-2), pp 7-14 (https://doi.org/10.1016/S0378-7753(00)00658-3).

66. Massányi, P.; Bárdos, L.; Roychoudhury, S.; Stawarz, R. J Environ sci and Heal. Part A, Tox/ Hazard Sub \& Environ Eng., 2012, 47 (9), pp 1201-1201 (https://doi.org/10.1080/10934529.2012. 672061).

67. Rai, P. K.; Lee, J.; Kailasa, S. K.; Kwon, E. E.; Tsang, Y. F.; Ok, Y. S.; Kim, K. H. Environ Res., 2018, 160, pp 420-448 (https://doi.org/10.1016/j.envres.2017.10.016).

68. Bielski, B. H.; Thomas, M. J. J A Chem Soc., 1987, 109 (25), pp 7761-7764 (https://doi. org/10.1021/ja00259a026).

69. Denvir, A.; Pletcher, D. J App Electrochem., 1996, 26 (8), pp 823-827 (https://doi.org/10.1007/ BF00683744).

70. Sharma, V. K.; Rivera, W.; Smith, J. O.; O’Brien. Environ Sci \& Tech., 1998, 32 (17), pp 2608-2613 (https://doi.org/10.1021/es970820k).

71. Luo, Z.; Strouse, M.; Jiang, J. Q.; Sharma, V. K. J Environ Sci and Heal, Part A, 2011, 46 (5), pp 453-460 (https://doi.org/10.1080/10934529.2011.551723).

72. Lee, Y.; Yoon, J.; von Gunten, U. Water Res., 2005, 39 (10), pp 1946-1953 (https://doi. org/10.1016/j.watres.2005.03.005). 
73. Yang, S. F; Doong, R. A. In: ACS Symposium Series. 2008, 985, pp 404-419. Oxford University Press. (https://doi.org/10.1021/bk-2008-0985.ch025).

74. Barışçı, S.; Ulu, F.; Sillanpää, M.; Dimoglo, A. J Chem Tech \& Biotech., 2016, 91 (1), pp 257-266 (https://doi.org/10.1002/jctb.4625).

75. Xu, X.; Wei, W.; Tao, P.; Zhang, Y. J Chem., 2014, 2014, pp 1-7 (http://dx.doi.org/10.1155/2014/640757).

76. Fernandes, H. M.; Reinhart, D.; Lettie, L.; Franklin, M. R.; Sharma, V.; Daly, L. J. Waste Management Symposium 2006, United States (https://inis.iaea.org/search/search.aspx?orig_ $\mathrm{q}=\mathrm{RN}: 40081203)$.

77. Haire, R. G. A Study of the Decomposition of Potassium Ferrate (VI) in Aqueous Solution, 1965, Department of Chemistry, Michigan State University, USA.

78. Jiang, J. Q.; Panagoulopoulos, A. In: Proceedings of the International Symposium of Innovative Ferrate (VI) Technology in Water and Wastewater Treatment. ICT Press, Prague, 2004, pp 67-73.

79. Sharma, V. K.; Luther III, G. W.; Millero, F. J. Chemosphere, 2011, 82 (8), pp 1083-1089 (https:// doi.org/10.1016/j.chemosphere.2010.12.053).

80. De Luca, S. J.; Cantelli, M.; De Luca, M. A. Water Sci and Tech., 1992, 26 (9-11), pp 2077-2080 (https://doi.org/10.2166/wst.1992.0665).

81. Batarseh, E. S.; Reinhart, D. R.; Daly, L. J Environ Eng., 2007, 133 (11), pp 1042-1050 (https://doi. org/10.1061/(ASCE)0733-9372(2007)133:11(1042)).

82. Rush, J. D.; Bielski, B. H. Inorg. Chem., 1989, 28 (21), pp 3947-3951 (https://doi.org/10.1021/ ic00320a004)

83. Diak, J.; Örmeci, B. J Environ Manage., 2018, 216, pp 406-420 (https://doi.org/10.1016/j. jenvman.2017.10.065).

84. Amano, M.; Lohwacharin, J.; Dubechot, A.; Takizawa, S. J Environ Manage. 2018, 212, pp 323331 (https://doi.org/10.1016/j.jenvman.2018.02.022).

85. Waite, T. D.; Gray, K. A. Stud. Environ. Sci., 1984, 23, pp 407-420 (https://doi.org/10.1016/S01661116(08)71247-0).

86. De Luca, S. J.; Chao, A. C.; Smallwood Jr, C. J Environ Eng., 1983, 109 (5), pp1159-1167 (https:// doi.org/10.1061/(ASCE)0733-9372(1983)109:5(1159)).

87. Graham, N.; Jiang, C. C.; Li, X. Z.; Jiang, J. Q.; Ma, J. Chemosphere, 2004, 56 (10), 949-956 (https://doi.org/10.1016/j.chemosphere.2004.04.060).

88. Sun, X.; Zhang, Q.; Liang, H.; Ying, L.; Xiangxu, M.; Sharma, V. K. J Hazard Mater., 2016, 319, pp 130-136 (https://doi.org/10.1016/j.jhazmat.2015.12.020).

89. Cooley, G. Removal of 2,4-dinitrophenol by Ferrate. Master's thesis, 2008, University of Central Florida, USA.

90. Lee, K. C.; Kim, I. K. Journal of Korean Society of Water and Wastewater, 2011, 25 (5), pp 643649 (http://www.koreascience.or.kr/article/JAKO201119074234192.page).

91. Al-Abduly, A.; Sharma, V. K. J Hazard Mater., 2014, 279, pp 296-301 (https://doi.org/10.1016/j. jhazmat.2014.06.083).

92. Lee, S. M.; Tiwari, D. J Environ Sci. 2009, 21 (10), pp 1347-1352 (https://doi.org/10.1016/S10010742(08)62425-0).

93. Yuan, B. L.; Qu, J. H.; Fu, M. L. Toxicon, 2002, 40 (8), pp 1129-1134 (https://doi.org/10.1016/ S0041-0101(02)00112-5).

94. Yang, B.; Ying, G. G.; Zhao, J. L.; Zhang, L. J.; Fang, Y. X.; Nghiem, L. D. J Hazard Mater., 2011, 186 (1), pp 227-235 (https://doi.org/10.1016/j.jhazmat.2010.10.106).

95. Jiang, J. Q.; Yin, Q.; Zhou, J. L.; Pearce, P. Chemosphere, 2005, 61 (4), pp 544-550 (https://doi. org/10.1016/j.chemosphere.2005.02.029).

96. Jiang, J. Q.; Zhou, Z.; Pahl, O. Sep. Purif. Technol. 2012, 88, pp 95-98 (https://doi.org/10.1016/j. seppur.2011.12.021). 
97. Lee, C.; Lee, Y.; Schmidt, C.; Yoon, J.; Von Gunten, U. Water Research, 2008, 42 (1-2), pp 433441 (https://doi.org/10.1016/j.watres.2007.07.035).

98. Anquandah, G. A.; Sharma, V. K.; Panditi, V. R.; Gardinali, P. R.; Kim, H.; Oturan, M. A. Chemosphere, 2013, 91 (1), pp 105-109 (https://doi.org/10.1016/j.chemosphere.2012.12.001).

99. Johnson, M. D.; Hornstein, B. J. Chem. Commun., 1996, (8), pp 965-966 (https://doi.org/10.1039/ CC9960000965).

100. Li, C.; Li, X. Z.; Graham, N.; Gao, N. Y. Water Research, 2008, 42 (1-2), pp 109-120 (https://doi.org/10.1016/j.watres.2007.07.023).

101. Pachuau, L.; Lee, S. M.; Tiwari, D. Chem. Eng. J., 2013, 230, pp 141- 148 (https://doi.org/10.1016/j.cej.2013.06.081).

102. Tiwari, D.; Sailo, L.; Pachuau, L. Sep. Purif. Techol., 2014, 132, pp 77-83 (https://doi.org/10.1016/j.seppur.2014.05.010). 